
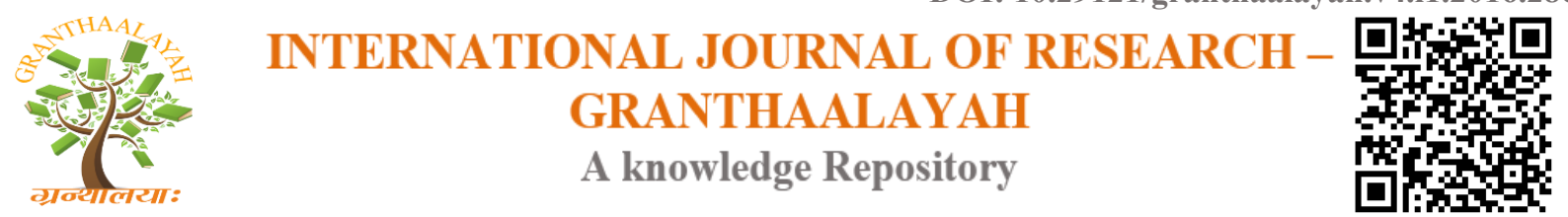

Science

\title{
BRIEF OVERVIEW ON HEPATITIS C VIRUS IMMUNOASSAYS
}

\author{
Rajesh K Sharma ${ }^{* 1}$, Pankaj K Sharma ${ }^{2}$, Gaush Talat ${ }^{3}$, Praveen Gautam ${ }^{4}$, \\ Reba Chhabra ${ }^{5}$, Surinder Singh ${ }^{6}$ \\ ${ }^{* 1,2,5,6}$ National Institute of Biologicals, Noida 201309, INDIA \\ ${ }^{3,4}$ Bench Biologist, National Institute of Biologicals, Noida 201309, INDIA
}

\begin{abstract}
The publication deals with a brief overview of Hepatitis C Virus (HCV) and donor blood screening for HCV by using conventional Rapid, Enzyme Linked Immunosorbent Assay (ELISA) and Chemiluminescence Immunoassay (CLIA) also. The advantages of various generation of $\mathrm{HCV}$ tests in terms of sensitivity, specificity and reduction in window period are discussed.
\end{abstract}

Keywords:

Hepatitis C Virus, Immunoassay, Enzyme Linked Immunosorbent Assay, Chemiluminescence Immunoassay.

Cite This Article: Rajesh K Sharma, Pankaj K Sharma, Gaush Talat, Praveen Gautam, Reba Chhabra, and Surinder Singh, "BRIEF OVERVIEW ON HEPATITIS C VIRUS IMMUNOASSAYS" International Journal of Research - Granthaalayah, Vol. 4, No. 1 (2016): 178-184.

\section{INTRODUCTION}

Human being has incredible creation of God having glandular important organ called liver. The utility list of this vital organ is so large and some its critical functions are to make some proteins important for blood clotting and other body functions, filtration of blood comes from digestive tract and to keep humans free from toxins and other harmful substances etc. The viral hepatitis is a common problem for public health in India. Different kinds of hepatitis viruses like A, B, C, D and $\mathrm{E}$ are the causative agent of the viral hepatitis [1]. The major root cause of viral hepatitis is either through contaminated water or infected blood or body fluids. The water borne viral hepatitis occurs either by Hepatitis A or Hepatitis E Virus. Hepatitis A Virus (HAV) and Hepatitis E Virus (HEV) can be prevented and controlled by maintenance of good hygiene, pure drinking water and fresh food etc. The Hepatitis B virus (HBV) Hepatitis C Virus (HCV) and Hepatitis D Virus (HDV) infection are transmitted through infected blood, plasma derivatives, organ, tissues and contaminated needles etc. and cause both acute as well as chronic disease. The $\mathrm{HBV}, \mathrm{HDV}$ and $\mathrm{HCV}$ are the major causative agent of the liver disease, liver cirrhosis, liver failure and even liver cancer. The infection of more than one type of viral hepatitis (HBV, HDV 
or $\mathrm{HCV}$ ) is much more severe and fatal for human being than the person infected with single viral hepatitis disease. It is evident from several studies that alcohol intake accelerates progression of viral hepatitis to cirrhosis.

In India, serological identification of HCV infection is generally based on the detection of HCV$\mathrm{Ab}$ by ELISA / CLIA / Rapid tests and confirmed by supplemental assays like Recombinant Immuno-Blotting Assay (RIBA) or Line Immuno Assay (Innolia) and / or Nucleic Acid Test (NAT), which uses Polymerase Chain Reaction (PCR) technology for HCV-RNA detection. NAT detects HCV-RNA at very early stage followed by HCV core Ag or fourth generation HCV $\mathrm{Ag}-\mathrm{Ab}$ test then HCV-Ab test. The use of highly sensitive HCV-Ab or HCV-Ag assay or HCV $\mathrm{Ag}-\mathrm{Ab}$ assay or HCV-RNA by NAT reduce the seroconversion window period and increase the opportunity of clinician to start treatment early after exposure of the $\mathrm{HCV}$ and prevent the public from HCV infection.

\section{HCV INFECTION}

HCV infection is a major public health problem not only for India but for all over the world also. $\mathrm{HCV}$ is implicated in $28 \%$ of cases of liver cirrhosis and $26 \%$ of cases of hepatocellular carcinoma worldwide, which accounts for almost 500,000 deaths per year[2,3] Population prevalence of chronic HCV infection in India is around 1 percent[4]. Different generation of anti-HCV assay can affect the prevalence rate in different population and practices between different regions of the country group[5]. Globally $\sim 170-180$ million persons are suffering with HCV[6]. Therefore, it is important to reduce the prevalence of HCV by blood collection from voluntary non-paid (non-remunerated) donors, proper screening of blood with advanced and highly sensitive serological and molecular assay. HCV infection resulting to hepatocellular carcinoma through various stages is as follow:

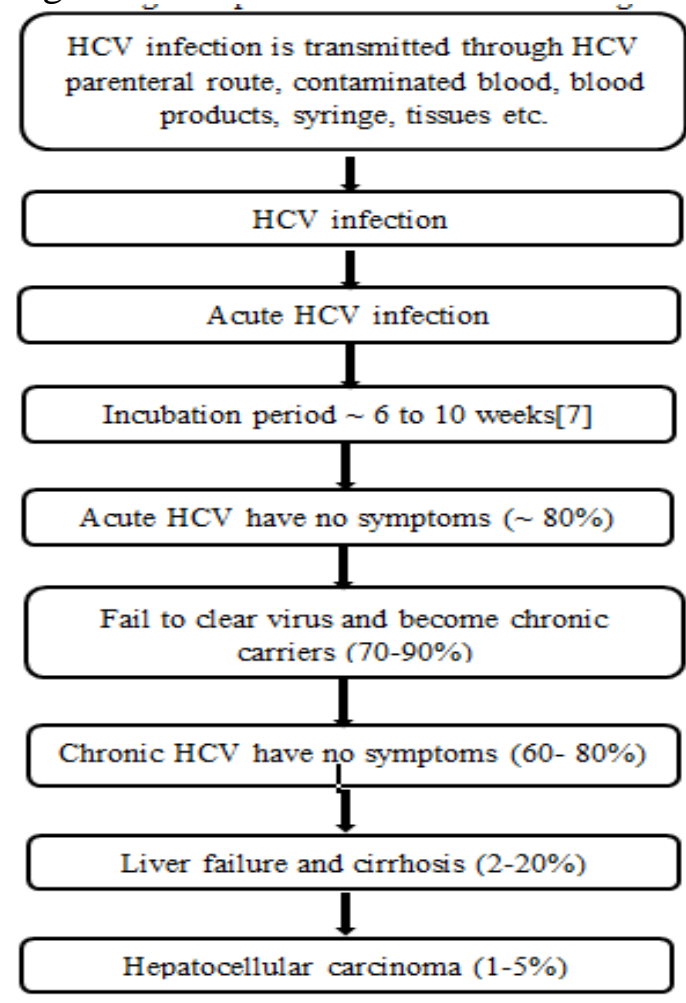




\section{STRUCTURE AND GENERAL CHARACTERISTICS OF HCV}

Previously Non-A Non-B Hepatitis (NANBH) finally characterized as a Hepatitis C virus (HCV) in year 1989[8]. It is a single stranded enveloped RNA virus having genome length of $\sim 9.5 \mathrm{~kb}$ and belongs to Hepacivirus genus of the family Flaviviridae. Structural and Non-Structural proteins comes under region encoding polyprotein precursor. The Structural protein contains a nucleocapsid protein (core) and two envelope glycoproteins (E1 and E2), and Non-Structural proteins contains NS1, NS2, NS3, NS4 and NS5 (Figure - 1).

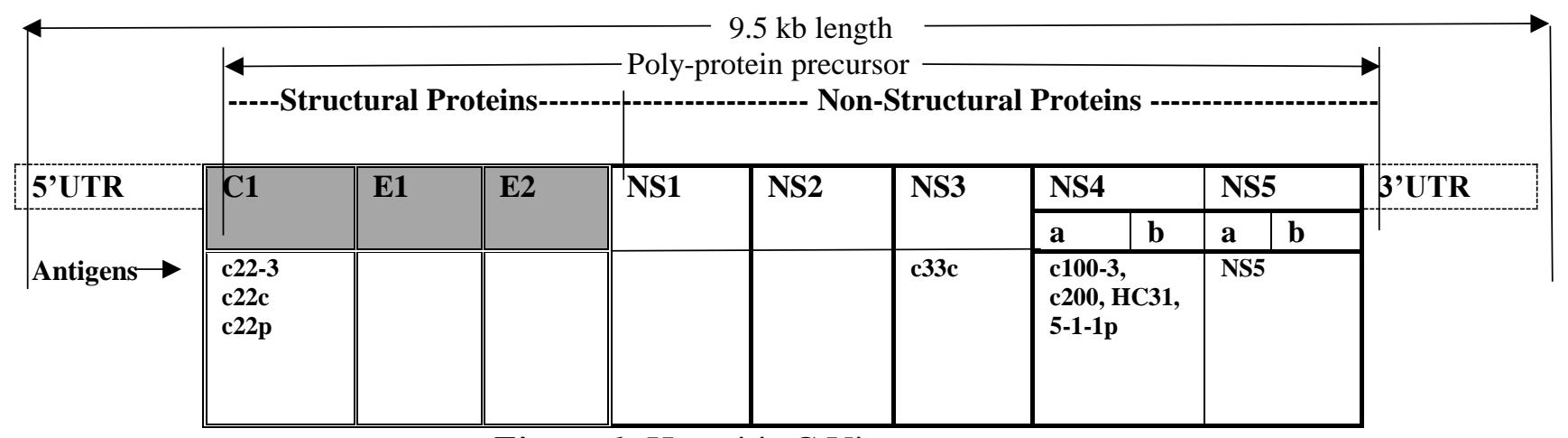

Figure 1: Hepatitis C Virus genome

\section{IMMUNOASSAY OF HCV}

Since development of Radio Immunoassay (RIA) in 1960 by Nobel prize winner Rosalyn Yelow and Solomon Berson[9] and ELISA by Engvali \& Perlmann in 1972[10] immunoassay becomes predominant immunological tool for detection of wide range of analytes specially for transfusion transmitted infection. Now a days detection of HCV infection basically depends on two types of test, one is serological tests which include rapid test, ELISA, CLIA, Supplemental assay (strip based like RIBA / Innolia) etc. and other is molecular diagnostic assay like HCV-RNA detection based on NAT. Serological test detects Antigen(Ag) or Antibody(Ab) or combo of Ag-Ab of $\mathrm{HCV}$ and molecular diagnostic test detects HCV RNA. ELISA for detection of HCV has progressed from $1^{\text {st }}$ generation to $4^{\text {th }}$ generation assay and manual test to automation test with enhanced detection capability. The $1^{\text {st }}$ generation ELISA for HCV was introduced in 1989[11] by using recombinant c100-3 derived from NS4 protein $[12,13]$. In $2^{\text {nd }}$ generation three end proteins were used and approved for use by US-FDA in 1992[13] with substantial improvement in sensitivity as well as in specificity[14]. For $3^{\text {rd }}$ generation assay NS5 is also incorporated to reduce window period and improve sensitivity and specificity. The fourth generation assay detects $\mathrm{HCV} \mathrm{Ag} \& \mathrm{Ab}$ both hence window period reduced further to average 26.8 days than 7-8 weeks required by third generation assay.

Table 1: Different generation of ELISA used for detection of HCV infection

\begin{tabular}{|l|l|l|}
\hline Generation & Coated material & Advantage / Disadvantage \\
\hline $1^{\text {st }}$ & $\begin{array}{l}\text { Single epitope of virus from NS4 } \\
\text { protein }\end{array}$ & $\begin{array}{l}\text { Poor sensitivity, long window period } \\
\text { between infection and detection (4-6 } \\
\text { months)[7] }\end{array}$ \\
\hline $2^{\text {nd }}$ & $\begin{array}{l}\text { Structural (core) and nonstructural } \\
\text { (NS3 and NS4) proteins }\end{array}$ & $\begin{array}{l}\text { Increased sensitivity than 1 } \\
\text { window peneration also } \\
\text { st }\end{array}$ \\
\hline
\end{tabular}




\begin{tabular}{|l|l|l|}
\hline $3^{\text {rd }}$ & $\begin{array}{l}\text { detection (10-24 weeks)[15] } \\
\text { (NS3 and NS4) proteins + NS5 }\end{array}$ & $\begin{array}{l}\text { Better sensitivity than 2 } \\
\text { window period between infection and } \\
\text { detection (7-8 weeks)[7] }\end{array}$ \\
\hline $4^{\text {th }}$ & $\begin{array}{l}\text { Structural (core) and nonstructural } \\
\text { (NS3, NS4 and NS5) proteins }+ \\
\text { Antibody (Antigen-antibody combo) }\end{array}$ & $\begin{array}{l}\text { Better sensitivity than 3 } 3^{\text {rd }} \text { generation also } \\
\text { window period between infection and } \\
\text { detection (average 26.8 days)[15] }\end{array}$ \\
\hline
\end{tabular}

Rapid immunoassays are used as alternative testing strategies in resource poor settings[16] and low testing burden. However these are is more costly than conventional immunoassay and not, therefore, intended for testing of large number of samples [17].

CLIA is an automated version of ELISA having high throughput which are useful to test and report large testing load blood banks / testing laboratories. Many CLIA based immunoassay are available in Indian market like M/s Abbott, M/s Bio-kit, M/s Ortho, M/s Roche \& Siemens etc. The details of five CLIA based assays are given in Table 2.

Table 2: Details of CLIA based assay for HCV Serology

\begin{tabular}{|c|c|c|c|c|c|c|}
\hline S. No. & Criteria & M/s Roche & M/s Siemens & M/s Abbott & M/s Ortho & M/s Biokit \\
\hline 1 & Analyzer & Cobas e411 & $\begin{array}{l}\text { Advia CentaurCP } \\
\text { Advia CentaurXP }\end{array}$ & $\begin{array}{l}\text { Architech i1000SR } \\
\text { Architech i2000SR }\end{array}$ & $\begin{array}{l}\text { Vitros ECi } \\
\text { Vitros } 5600\end{array}$ & Bio-Flash \\
\hline 2 & $\begin{array}{l}\text { Assay } \\
\text { pack }\end{array}$ & $100 \mathrm{~T} / 200 \mathrm{~T}$ & $200 \mathrm{~T}$ & $100 \mathrm{~T} / 500 \mathrm{~T}$ & $100 \mathrm{~T}$ & $100 \mathrm{~T}$ \\
\hline 3 & $\begin{array}{l}\text { Type of } \\
\text { assay }\end{array}$ & $\begin{array}{l}\text { Sandwich } \\
\text { immunoassay }\end{array}$ & $\begin{array}{l}\text { Sandwich } \\
\text { immunoassay }\end{array}$ & $\begin{array}{l}\text { Chemiluminescent } \\
\text { microparticle } \\
\text { immunoassay }\end{array}$ & $\begin{array}{l}\text { Sandwich } \\
\text { immunomrtric }\end{array}$ & $\begin{array}{l}\text { Chemiluminescent } \\
\text { microparticle } \\
\text { immunoassay }\end{array}$ \\
\hline 4 & Principle & ECLIA & CLIA & CLIA & CLIA & CLIA \\
\hline 5 & Duration & $18 \mathrm{~min}$ & $40 \min$ & $40 \mathrm{~min}$ & $55 \mathrm{~min}$ & $30 \min$ \\
\hline 6 & $\begin{array}{l}\text { Type of } \\
\text { Ag }\end{array}$ & $\begin{array}{l}\text { Peptide \& } \\
\text { recombinant } \\
\text { Ag } \\
\text { representing } \\
\text { core, NS3 \& } \\
\text { NS4 proteins }\end{array}$ & c200 \& NS5 & $\begin{array}{lll}\text { HCr43, } & \text { c200 } & \& \\
\text { NS5 } & & \end{array}$ & $\begin{array}{l}\text { cC22-3, c200 } \\
\text { \& NS5 }\end{array}$ & $\begin{array}{l}\text { Core, NS3, NS4 } \\
\& \text { NS5 }\end{array}$ \\
\hline \multirow[t]{3}{*}{7} & \multirow[t]{3}{*}{$\begin{array}{l}\text { Reagents / } \\
\text { coating }\end{array}$} & $\begin{array}{l}\text { Streptavidin } \\
\text { coated } \\
\text { microparticle }\end{array}$ & $\begin{array}{lr}\text { Anti-human } & \text { IgG } \\
\text { monoclonal } & \mathrm{Ab} \\
\text { labeled with ester } \\
\text { in buffer with } \\
\text { bovine serum } \\
\text { albumin, sodium } \\
\text { azider and } \\
\text { surfactant }\end{array}$ & $\begin{array}{l}\mathrm{HCV} \mathrm{Ag} \text { coated } \\
\text { paramagnetic } \\
\text { microparticles }\end{array}$ & $\begin{array}{l}\text { Horse Radish } \\
\text { Peroxidase } \\
\text { (HRP) } \\
\text { labelled Ab } \\
\text { conjugate }\end{array}$ & $\begin{array}{l}\mathrm{HCV} \mathrm{Ag} \text { coated } \\
\text { para magnetic } \\
\text { microparticles }\end{array}$ \\
\hline & & $\begin{array}{l}\text { Biotinylated } \\
\mathrm{HCV} \text { specific } \\
\mathrm{Ag}\end{array}$ & $\begin{array}{l}\text { Streptavidin } \\
\text { coated } \\
\text { paramagnetic } \\
\text { microparticle } \\
\text { Biotinylated } \\
\text { recombinant } \\
\text { c200 HCV Ag \& } \\
\text { c22p Ag }\end{array}$ & $\begin{array}{l}\text { Anti-human } \\
\text { acridinium labelled } \\
\text { conjugate }\end{array}$ & $\begin{array}{lr}\begin{array}{l}\text { Human } \\
\text { captured }\end{array} & \text { IgG } \\
\text { well } & \end{array}$ & $\begin{array}{lr}\text { Mouse } & \\
\text { monoclonal } & \text { Anti- } \\
\text { human } & \text { IgG } \\
\text { labelled } & \text { with } \\
\text { isoluminal } & \end{array}$ \\
\hline & & HCV specific & Biotinylated & Tris buffer with & Luminol & Isoluminal \\
\hline
\end{tabular}




\begin{tabular}{|l|l|l|l|l|l|l|}
\hline & & $\begin{array}{l}\text { Ag labelled } \\
\text { with } \\
\text { ruthenium } \\
\text { complex }\end{array}$ & $\begin{array}{l}\text { recombined NS5 } \\
\text { Ag in buffer with } \\
\text { sodium azide }\end{array}$ & protein stabilizer & $\begin{array}{l}\text { derivative \& } \\
\text { peracidsat }\end{array}$ & $\begin{array}{l}\text { labelled } \\
\text { monoclonal } \\
\text { antibody }\end{array}$ \\
\hline 8 & $\begin{array}{l}\text { Clinical } \\
\text { sensitivity }\end{array}$ & $100 \%$ & $100 \%$ & $99.10 \%$ & $99.54 \%$ & $100 \%$ \\
\hline 9 & $\begin{array}{l}\text { Clinical } \\
\text { Specificity }\end{array}$ & $99.84 \%$ & $99.90 \%$ & $99.60 \%$ & $98.22 \%$ & $99.70 \%$ \\
\hline
\end{tabular}

Source: Leaflets of CLIA of each manufacturer

\section{DISCUSSION}

Once the hepatitis $C$ virus entered in an individual the virus starts multiplication and develops $\mathrm{HCV}$ RNA followed by HCV-Ag and HCV-Ab but screening of blood is usually done for HCV$\mathrm{Ab}$ test and may be followed by supplemental test \{Recombinant Immuno-Blotting Assay (RIBA) or Line Immuno Assay (Innolia)\} / HCV-Ag or HCV-RNA. The HCV RNA is detectable by PCR as early as 1 week after exposure and HCV Ab develops in 2-6 weeks in acute infection but in some cases HCV Ab may not be positive for 6-9 months [7]. The cost of the machine, reagents and requirement of highly expertise technical person are the biggest challenges for using NAT. Hence, window period of HCV is increased till development and detection of $\mathrm{HCV}-\mathrm{Ab}$. The currently available $\mathrm{HCV}-\mathrm{Ab}$ assay detects antibody at 6-8 weeks after the onset of infection[5] whereas HCV Ag appears within 2-8 days of HCV RNA detection[15]. Generally, screening assay is used for detection of HCV-Ab in the blood banks / diagnostic center but it does not discriminate between cleared infection and chronic infection $[18,19,20]$. Therefore, it would be better if blood banks / diagnostic center use either HCV core Ag detection assay or $\mathrm{HCV} \mathrm{Ag}-\mathrm{Ab}$ detection assay for screening because $\mathrm{HCV}-\mathrm{Ag}$ is developed before the $\mathrm{HCV}-\mathrm{Ab}$ and / or HCV RNA by Nucleic acid testing (NAT). CLIA for HCV is also a choice for those blood banks and laboratories which has tremendous work load of screening of blood which is an automation of immunoassay, therefore, it reduces the human error(s) if occurs during testing. Overall, the use of HCV fourth generation screening assays based on ELISA or CLIA is worth for $\mathrm{HCV}$ detection as viral window period is reduces from 4-6 months ( ${ }^{\text {st }}$ generation assay) to about a month ( $4^{\text {th }}$ generation assay).

\section{REFERENCE}

[1] Global Alert \& Hepatitis (GAR) Hepatitis, World Health Organization (WHO).

[2] Lozano R., Naghavi M., Foreman K. et al. Global and regional mortality from 235 causes of death for 20 age groups in 1990 and 2010: a systematic analysis for the Global Burden of Disease Study 2010. Lancet.2012 Dec;15:380(9859)2095-128. doi: 10.1016/S0140-6736(12)61728-0.

[3] Radha K. Dhiman. Future of therapy for Hepatitis $C$ in India: A Matter of Accessibility and Affordability?; J Clin Exp Hepatol. 2014 Jun;4(2): 85-6. doi: 10.1016/j.jceh.2014.06.011.

[4] Manoj Kumar \& Shiv K. Sarin. Viral hepatitis eradication in India by 2080 - gaps, challenges \& targets Indian J Med Res 2014 Jul; 140(1):1-4. 
[5] Ekta Gupta, Meenu Bajpai and Aashish Choudhary. Hepatitis C virus: Screening, diagnosis, and interpretation of laboratory assays. Asian Journal of Transfusion Science. 2014, Jan-Jun, 8(1): 19-25. Doi: 10.4103/0973-6247.126683.

[6] Francois Rouet, Luc Deleplancque, Berthold Bivigou Mboumba, Jeanne Sica, Augustin Mouinga-Dndeme, Florian Liegeois, Alain Goudeau, Frederic Dubois and Catherine Gaudy-Graffin. Usefulness of a Forth Generation ELISA Assay for the Reliable Identification of HCV infection in HIV-Positive Adults from Gabon (Central Africa). PLos One. 2015 Jan; 10(1): e0116975. Doi: 10.1371/jornal.pone.0116975.

[7] Global Alert and Response (GAR). Hepatitis C. www.who.int/csr/disease/ hepatitis/ whocdscsrlyo2003/en/index4.html.

[8] Choo Q L, Kuo G, Weiner A J, Overby L R, Bradley D W, Houghton M. Isolation of a cDNA clone derived from a blood-borne non-A, non-B viral hepatitis genome. Science, 1989 Apr 21:244(4902):359-62.

[9] Yelow R. S. \& Berson S.A. Immunoassay of endogenous plasma insulin in man. J Clin Invest. 1960 July, 39(7): 1157-75.

[10] Graham A, Bonwick \& Christopher J. Smith. Immunoassay: their history, development and current place in food science and technology. International Journal of Food Science and Technology. 2004 Oct, 39(8):817-827. Doi: 10.1111/j.1365-2621.2004.00855.

[11] Ismail N, Fish G.E. and Smith M.B.. Laboratory evaluation of a fully automated chemiluminescence immunoassay for rapid detection of HBsAg, antibodies to HBsAg and antibodies to hepatitis C virus. J. Clin Microbiol. 2004 Feb;42(2):610-7.

[12] Kuо G, Choo QL, Alter HJ, Gitnick GL, Redeker AG, Purcell RH, Miyamura T, Dienstag $J L$, Alter MJ, Stevens CE et al. An assay for circulating antibodies to a major etiologic virus of human non-A, non-B hepatitis. Science.1989 Apr 21: 244(4902):362-4.

[13] Sinyoung Kim, Jeong-Ho Kim, Seoyoung Yoon, Youn-Hee Park and Hyon-Suk Kim. Clinical performance evalution of four automated chemiluminescence immunoassay for hepatitis C virus antibody detection. J Clin Microbiol. 2008 Dec;46(12): 3919-3923.

[14] Poduri CD. Hepatitis C virus (HCV) - A Review Molecular biology of the virus, immunodiagnostics, genomic heterogeneity and the role of virus in hepatocellular carcinoma. Indian Journal of Experimental Biolology. 2003, June;41:549-562.

[15] Neelam Marwaha and Suchet Sachdev. Current testing strategies for hepatitis C virus infection in blood donors and the way forward. World Journal of Gastroenterology. 2014 Mar; 21 20(11):2948-54. doi: 10.3748/wjg.v20.i11.2948.

[16] Sharma R. K., Kumar Rajeev, Sharma Nitika, Chhabra reba, Soni G. R. and Singh Surinder. Stability of rapid Human Immunodeficiency Virus (HIV) tests beyond their recommended storage temperature. International Journal of Biomedical and Advance Research. 2015; 6(10):705-08. Doi:10.7439/ijbar.

[17] Saleem Kamili, Jan Drobeniuc, Aufra C. Araujo and Tonya M Hayden. Laboratory Diagnostics for Heaptitis C Virus Infection. Clinical Infectious Diseases. 2012:55(S1):S43-8. Doi: 10.1093/cid/cis368.

[18] Curry MP, Chopra S. Acute viral hepatitis. In: Mandell GL, Bennett JE, Dolin R, editors. Mandell, Douglas and Bennett's principles and practice of infectious diseases. Philadelphia: Churchill Livingstone; 2010,1577-92.

[19] Menha Swellam, Magda Sayed Mahmoud and Adel Abdel-Fatah Ali. Diagnosis of Hepatitis $C$ Virus Infection by Enzyme-linked Immunosorbent Assay and Reverse 
Transcriptase-Nested Polymerase Chain Reaction: A Comparative Evaluation. IUBMB Life, 2011, June 63(6): 430-434. doi: 10.1002/iub.469 IUBMB Life, 63(6): 430-34.

[20] Anita Chakravarti, Mayank S. Chauhan, Gaurav Dogra, Sayantan Banerjee. Hepatitis C virus core antigen assay: can we think beyond convention in resource limited settings? Brazilian Journal of Infectious Diseases. 2013 May/June; 17(3). doi.org/10.1016/j.bjid.2012.10.028. 